\title{
Ensinar, mover e deleitar: práticas de leitura do texto religioso em Portugal entre os séculos XVI eXVIII
}

To teach, to move and to delight: reading practices of the religious text in Portugal between the sixteenth and eighteenth centuries

Thiago Maerki ${ }^{1}$

Resumo: A leitura de textos religiosos produzidos entre os séculos XVI e XVIII, com vistas à catequese e à ação cristã, não pode ser desassociada também da finalidade de "entreter o espírito". Neste artigo, examinamos como se deu essa problemática em Portugal, colhendo exemplos principalmente de textos hagiográficos, que, nesse período, ombreavam com obras ditas profanas no que diz respeito à leitura para o deleite.

Palavras-chave: Práticas de leitura. Deleite. Hagiografia. Texto religioso.

Abstract: The reading of religious texts produced between the sixteenth and eighteenth centuries, aiming at catechesis and Christian action, cannot also be dissociated from the purpose of "entertaining the spirit". In this paper, we examine the way this situation used to take place in Portugal, taking examples mainly from hagiographical texts, which, during this period, matched the so-called profane works in regards to reading for delight. Keywords: Reading practices. Delight. Hagiography. Religious text.

1 Pesquisador independente. Doutor em Teoria e História Literária pela Universidade Estadual de Campinas (Unicamp). 


\section{Introdução}

Em Ethics through literature. Ascetic and aesthetic reading in Western Culture (2007), Brian Stock apresenta o que, para ele, são os dois modos de leitura presentes na cultura ocidental: a "leitura ascética" e a "leitura estética". Esta teria relação com a "imaginação criativa" (2007, p. 1); aquela com a questão ética ou moral. Essas duas práticas de leitura, segundo o autor, não estavam estabelecidas por meio de fronteiras claramente demarcadas, contudo se permutavam de tal modo que poderíamos falar em "ensinamento ético por meio da literatura" (STOCK, 2007, p. 1). Tal abordagem pode sugerir a presen-

Thiago

Maerki ça de duas maneiras distintas de leitura - apesar de Stock reconhecer a não existência de fronteiras entre elas -, o que não se confirma, do ponto de vista cristão, pelo menos antes de finais do século XVIII. A prática de leitura de textos religiosos na Idade Moderna não se dividia em momentos de ensino e de deleite, porque mesmo este tinha como finalidade "entreter o espírito" e, numa última e principal consequência, a salvação da alma. Sendo assim, ensino e diversão engendravam, na verdade, um único modo de leitura possível, não podendo ser separados em estatutos autônomos.

No que diz respeito às "Vidas de santo", quando estudiosos aproximam hagiografia e arte, geralmente procuram demonstrar aspectos comuns a elas com a finalidade de comprovar que esse tipo de texto pode ser também formado por uma poética. Para isso, geralmente, associam santos a heróis; procuram identificar elementos - uma ars ou uma retórica - comuns à hagiografia e à biografia greco-romana; demonstram como textos sobre santos estão repletos de elementos provindos do folclore; e como, do ponto de vista formal, se aproximam de narrativas breves, como a do conto popular (MORENO, 2008). Muitas vezes, evidenciam seu caráter catequético, colocando em segundo plano, ou, até mesmo, desconsiderando a leitura deles sob o propósito de deleite. Esse duplo objetivo, docere e delectare, pode ser atribuído à hagiografia, que, além de edificar por meio de vidas exemplares, agrada mediante um meticuloso uso da linguagem, tendo como efeitos a surpresa e a admiração, decorrentes da leitura, por exemplo, e especialmente, de mirabilia, presente não somente nos textos hagiográficos medievais, mas também naqueles produzidos após esse período (MORENO, 2008).

Não há dúvidas de que os textos religiosos e especialmente aqueles sobre santos, independentemente da tipologia textual pela qual foram veiculados (crônicas historiográficas, legendas, Vidas, sermões, poesia, etc.), tenham como objetivo primordial a conversão dos costu- 
mes de seu público leitor. No entanto, o aspecto moral e moralizante avulta-se de tal maneira que leva a muitos a desconsiderarem - alguns talvez até a não acreditarem - que os textos religiosos fossem lidos por passatempo, que possuíssem também como uma de suas finalidades a distração, ou, como aparece anotado em alguns textos que examinaremos nas páginas seguintes, para "entreter o espírito".

\section{Leitura e deleite em textos religiosos e hagiográficos}

Muitos textos religiosos produzidos a partir de Quinhentos ou até

Ensinar, mesmo um pouco antes, estão repletos de referências à leitura para movere “entreter o espírito". É nesse sentido que o espanhol Frei Alonso de Madeleitar dri (1485-1570), no início do capítulo XI de seu Espejo de ilustres personas (1524), recomenda o "passatempo prazenteiro" (1948, p. 200), sem que isso se torne vicioso, o que ele chama de "honesta recreación" (1948, p. 200). Com tal expressão, o místico franciscano reconhece a possibilidade de deleite, todavia defende que por mais que se tenha a necessidade de recreação, deve-se antes morrer que fazer coisa ociosa. No que se refere especificamente à leitura, a orientação de muitos autores do mesmo período, como veremos, parece ser a mesma.

Naturalmente não é difícil imaginar que os textos sobre santos ocupassem lugar de destaque quando se desejava um tempo para folgar ou descansar. Há casos também em que eles serviam de inspiração para a criação artística, como apreendemos dos testemunhos do médico espanhol Santiago Ramón y Cajal (1852-1934), que lia as "Vidas dos santos" para fugir ao tédio e instigar a criatividade ao se dedicar às artes plásticas (MORENO, 2008). De igual modo, nos três séculos anteriores, os textos sobre santos foram lidos também com o mesmo intuito ou, ao menos, com propósitos muito semelhantes, não se destinando exclusivamente à instrução catequética.

Embora o termo "entretenimento", que temos empregado, possa causar estranheza ao ser relacionado a obras dadas à luz entre os séculos XVI e XVIII, fora utilizado por alguns autores desse período. A Sylva Spiritual de varias consideraciones, para entretenimiento del alma Christiana (em duas partes: 1590), escrita pelo franciscano Frei Antonio Alvarez (?1598), é um exemplo. No "Prologo al lector", o autor recrimina aqueles que se dedicam à leitura de textos que induzem ao vício, como as "coplillas con sus lasciuas tonadas" e as "comedias y representaciones no poco peligrosas para las consciências" (ALVAREZ, 1590, página inumerada). Depois, Alvarez declara que o objetivo de sua "silva espiritual" é 
[...] hazer vna maneira de entretenimiento Christiano, sino ya tanto para impedir a los hombres perdidos e olvidados de Dios de los suyos mundanos [...] alomenos si quiera para que en el entretanto que estos se occupan en aquellos profanos, los otros bien considerados tengan esta Syluezilla en que entretenerse, passando sus ratos en la consideracion de los diuinos mysterios, de que ella trata, y en algun aprouechamiento para sus almas [...] (1590, páginas inumeradas).

Thiago

Maerki

Apreende-se do fragmento a proposição de uma obra que proporcione também o deleite a exemplo de obras ditas profanas; o autor sugere o "entretenimento cristão", que se contrapõe diretamente ao "entretenimento profano" ou "mundano". A expressão "passando sus ratos", por sua vez, refere-se a "matar o tempo" ou a "passatempo", momento em que a leitura é realizada com a finalidade de folgar sem, no entanto, perder de vista o fundamento da fé cristã, ou seja, o "aproveitamento para a alma". Frei Marcos de Lisboa sugere algo muito parecido em suas Crônicas da Ordem dos Frades Menores (1556) ao criticar aqueles que perdem seu tempo na leitura de obras pagãs, às quais ele contrapõe os textos cristãos, principalmente as Vidas de santos apresentadas em sua obra:

Teueram os antigos naturaes muita diligencia, em se aproueitarem \& animarem com os exemplos dos seus illustres varões, \& delles faziam esporas pera a virtude, porque em nenhum tempo desfalecessem à obrigaçam de sua patria e honra. E os exemplos seus muy notaueis, queriam que fossem o leite com que a seus filhos criassem nas escolas insinados nas poesias, historias, orações, per os quaes exemplos os moços se affeiçoassem a virtude, \& tomassem spiritos \& desejos de alcançar gloria mais vaam que verdadeira, $\mathrm{E}$ foy tanta a sua diligencia nisto, que bastou não so pera os seus, mas tambem pera converter a muitos Christãos a seus costumes \& criação, os quaes gastam sua primeira idade em aquellas memorias dos antigos Gregos ou latinos, \& oxalá se não gastasse toda a vida de muitos, em que mayor parte tem Homero, Virgilio, ou Cicero, que Christo. O que he digno de muita reprehensam, pois na verdade não sam dignos de louuar \& 
muito menos de ser imitados em o negoceo da virtude, os antigos supersticiosos gentios, os quaes como carecem de fee \& verdadeira luz que so alumia \& faz bom o coraçam humano, assi nem teueram verdadeira virtude, mas aparente cega \& vam [...] (LISBOA, 1614, página inumerada).

A partir desse excerto, é possível inferir que os pagãos utilizavam suas obras como modelo de conduta, para que, imitando os exemplos propostos, os leitores atingissem a virtude e a honra. Os autores pagãos são acusados de desviarem muitos cristãos do caminho da perfeição, fazendo com que estes se interessassem mais por Homero, Virgílio e Cícero que por Cristo. As Crônicas são entendidas, pois, como obra superior à dos autores clássicos citados, pois apresentam a história de homens detentores Ensinar, movere deleitar da verdadeira virtude, diferentemente dos pagãos, que cultivavam uma virtude vã, como toda virtude não influenciada pela "verdadeira luz que faz bem ao coração humano". Apesar de Frei Marcos evidenciar, nesse fragmento, o aspecto moral, não seria inverossímil supor que desejasse também, a exemplo dos mesmos textos pagãos que critica, que suas crônicas fossem lidas também com o propósito do deleite.

Coleçaõ, e escolha de bons ditos, e pensamentos moraes, políticos, e religiosos. Para recreaçaõ das pessoas judiciozas, e para enterter as horas, que naõ saõ de estudos especulativos (1779), esse é o título de uma obra anônima publicada em Lisboa pela oficina de Francisco Borges de Souza e que sugere o mesmo entendimento do vocábulo "entreter". o objetivo dela, como o próprio título indica, situa-se na contramão dos "estudos especulativos", ou seja, que possuem um viés teórico, desconsiderando o aspecto empírico da vivência. Essa coleção de ditos, ao contrário, destina-se à "recreação" e a "entreter as horas" - para o entretenimento, diríamos hoje -, mas não perde de vista o objetivo de ensinar, ou seja, o aspecto moral. No "Prologo", tal intenção é apregoada pelo próprio autor, que, após afirmar que esse tipo de obra fora sempre cultivado por todas as nações, desde os gregos e romanos, lembra que em seu tempo também é uma lição muito estimada, "pois as pessoas judiciozas se agradaõ della, naõ só para descançarem dos estudos sérios, e especulatiuos, mas para socorro, e istrucçaõ dos entendimentos vivos" (página inumerada). "Descanso" e "instrução", portanto, são os objetivos que movem a reunião desses "bons ditos". O mesmo se poderia afirmar de obras com o mesmo perfil, como a Coleção moral de apotegmas (Parte I: 1732; Parte 2: 1761), de Pedro José 
Supico de Moraes (17?), e a Nova floresta, ou sylva de varios apophthegmas, e ditos sentenciosos, e moraes (entre 1706 e 1728, em cinco tomos), do Padre Manuel Bernardes (1644-1710). No primeiro tomo dessa última obra, na "Reflexão, e razão da obra ao benevolo Leytor", criticam-se aqueles que se dizem cansados e atormentados por ouvirem meia hora de missa, mas, por outro lado, parece-lhes breve estar na casa de jogo ou no pátio das comédias toda a noite ou toda a tarde. Recriminam-se também aqueles que dizem desperdiçar o tempo de seus negócios ao irem se confessar e o confessor não os admite logo; depois, "jà confessado, anda buscando em que passar horas e as consome com Epicuro, em regalos sensuais, ou como Momo ${ }^{2}$ em conversações detractivas" (1706, página inumerada). Depois Bernardes revela o objetivo de sua obra: "pertendemos que as [horas] de passatempo naõ sejaõ tam longas; porque a liçaõ honesta he hum dos proveytosos empregos, que lhes podemos dar" (1706, página inumerada). Apesar de não valorizar o que chama de "horas de passatempo", Bernardes reconhece, entretanto, que delas o cristão poderá tirar proveito se não forem tão longas. o que está em jogo, evidentemente, é a crítica àqueles que reclamam dos longos períodos de oração, contudo passam horas em atividades inúteis à salvação, como jogos, comédias e conversas detrativas, indecentes. Ele propõe que as horas de passatempo sejam empregadas para a salvação dos cristãos, que, por meio de uma breve lição - brevidade inerente, diga-se de passagem, ao gênero dos apotegmas -, podem fazer do tempo de deleite também um momento de assimilação da doutrina, como, inclusive, é sugerido no título da obra.

o ponto de partida para entendermos a hagiografia como texto destinado também ao deleite surgiu de uma passagem das citadas Crônicas na qual Frei Marcos de Lisboa parece indicar os variados destinatários de sua obra. Vejamo-la:

\footnotetext{
Se es inclinado a caualaria, veras aqui nobres feitos \& façanhas, contra os demonios derrocados \& vencidos pelos caualeiros de Christo. Se folgas com honras, acharàs aqui quaõ honrados saõ os amigos de Deos, dos cidadãos dos ceos \& das terras, \& temidos dos infernaes. Se te delecta a sciencia, aqui aprenderàs o conhe-
}

2 Na mitologia grega, Momo é a personificação do sarcasmo e da burla. Baltasar Gracián (1601-1658) apresenta-o na segunda parte de El criticón (em três partes: 1651; 1653; e 1657), especificamente no capítulo "El texado de vidrio y Momo tirando piedras". As características dessa personagem fizeram com que fosse frequentemente retratada alegórica e artisticamente nas obras ditas "emblemáticas", entre os séculos XV e XVIII. 
cimento verdadeiro \& praticado das falsidades do mundo, \& a verdadeira sapiencia do conhecimento proprio \& de seu Criador. Se es actiuo ou contemplativo, aqui acharas grandes experiencias \& praticadas virtudes, \& altas contemplaçoẽs da communicaçaõ diuina. Finalmente se te prezas de Christão, \& as partes do bõ Christão debuxadas em duas tauoas, em viuos exẽplos de vida, \& sancta doctrina, ambas necessarias pera o verdadeiro conhecimento da saluaçaõ. Assi que pera todos teus desejos \& necessidades acharàs conueniẽtes remedios, nas vidas \& exemplos dos seruos de Deos os frades Menores (1614, página inumerada).

Ensinar, movere deleitar

O trecho pode ser divido em duas partes que apresentam, cada uma, grupos distintos de possíveis leitores. O primeiro compreende pessoas inclinadas à cavalaria, as que aspiram à honra e os amantes da ciência. O segundo grupo, por sua vez, é formado por religiosos de vida ativa (pregadores, missionários e padres seculares) e contemplativos (eremitas e monges). Frei Marcos arremata o excerto afirmando, enfim, que as Crônicas destinam-se a todos quantos se consideram cristãos.

o primeiro período do excerto - "se és inclinado à cavalaria, verás aqui nobres feitos e façanhas contra os demônios derrocados e vencidos pelos cavaleiros de Cristo" - é extremamente importante para compreender as Crônicas enquanto texto lido também com a finalidade de deleite. Associar as narrativas santorais à novela ou ao romance de cavalaria é estratégica argumentativa do autor para atingir, ao menos, dois objetivos específicos. O primeiro é apresentar narrativas que possam substituir a leitura de "obras profanas", e, numa chave de leitura contrarreformista, também combatê-las, numa estratégia textual largamente utilizada pelos autores do século XVI. O outro objetivo é recomendar as legendas santorais àqueles ávidos por uma "boa leitura", para os "momentos de folga", para a recreação. Dessa forma, Frei Marcos sugere que, se o desejo do leitor é "folgar", as Vidas dos santos são melhores que os "textos profanos", pois elas não os levarão a perder suas almas.

De forma análoga, o poeta canário Bartolomé Cairasco de Figueroa (1538-1610), no prólogo “Al lector”, presente na primeira parte de sua obra Templo Militante Flos Sanctorum, y Trivmphos de svs virtvdes (1602-1614, em 4 partes) - um Flos Sanctorum em verso de grande sucesso no início do século XVII que oferece, em sua quarta parte, uma 
interessante composição poética em oitavas dedicada a S. Francisco de Assis, dividida em três cantos -, chama a atenção de seus leitores para o perigo da leitura de "obras profanas", recomendando, em contrapartida, as Vidas de santos como passatempo e diversão:

Thiago

Maerki

Llegado es el tiempo, Christiano, y curioso Lector, en que dando de mano a las profanas y fabulosas poesias, que (sin ofender a lo que es agudeza de ingenio) tan estragados tienen los entendimientos, y gustos humanos, puedas entretenerte con otras verdadeiras, y santas [...]. Y assi, si te dauan gusto, y passatiempo Boscanes, Orlandos, Gofredos, y sus ymitadores, con ingeniosas aventuras, y memorables hechos. Aqui hallaràs afectos, y sentimientos amorosos, Principes, y Caualleros, tanto mas firmes y discretos, valerosos, y gallardos [...]. Y si te agradaron Archadias, Dianas, Galateas, y Philidas, sus imaginados amores, y bellezas: aqui veràs Nimphas, y Pastoras hermosissimas, que enamoraron, no a los hombres mortales, sino al q̃ enamorado dellos les comprò la vida con su muerte. $Y$ en fin, si te entretenias, y gustauas de artificiosas comedias, Toscanas, y Españolas, $\mathrm{y}$ de su estraña pompa, y costoso aparato. Aqui veràs recitantes fomosissimos, que en los amphiteatros, y Scenas mas celebres del mundo recitaron de manera, que agradando al Rey del Cielo, y a su Corte soberana assombraron a los Emperadores, y tiranos de la tierra [...]. No te prometo milagros, ni assombros poeticos, sino verdades claras, y llanezas humildes, que para historia de Santos es lo que importa (1613, página inumerada).

É notável o esforço do autor em rechaçar os textos pagãos à medida que destaca os objetivos do Flos Sanctorum que prefacia. Sua obra, como as Crônicas, destina-se a um público também vário, cujo gosto deseja satisfazer, além de entretê-lo com poesias "verdadeiras e santas". O vocábulo "passatiempo" é empregado por Figueroa, o que também confirma nossa hipótese de leitura das Vidas de santos por prazer. Naturalmente, por se tratar de obra escrita em versos, o Templo Militante tem também como objetivo a "diversão espiritual" de seus leitores. Além disso, forma e conteúdo estreitam-se para atingir essa finalidade, já que as histórias dos santos estão repletas de aventuras e de feitos memoráveis, assim como de sentimentos amorosos de prín- 
cipes e cavaleiros e de amores de ninfas e pastoras. Portanto, a leitura dessas hagiografias em verso poderia substituir a leitura de obras profanas e de "poesias fabulosas", ávidas por confundir o entendimento. No entanto, apesar da possibilidade do deleite, o excerto destaca que o principal objetivo não são os "assombros poéticos" ou os eventos miraculosos que podem ocasioná-los, mas as "verdades claras", que devem ser emuladas pelos leitores.

As Crônicas e o Templo Militante são bons exemplos da prática de leitura para "entreter o espírito". Não é difícil imaginar que também os sermões fossem lidos e ouvidos, não só, mas também com o mesmo propósito. O prólogo da segunda parte dos Sermoẽs do dovto Diogo de Payva D'Andrade (1604) - escrito pelo sobrinho do autor, responsável por recolher sermões manuscritos do tio e dá-los à estampa - pode dar pisEnsinar, movere deleitar tas preciosas sobre esse aspecto. $O$ dito sobrinho afirma que procurou reunir sermões encomendados ao tio por príncipes e outras pessoas, os quais "elle aceitaua quando podia cõ muita facilidade" (1604, fol. v). Essa informação dá notícias sobre os possíveis destinatários desses sermões, ouvidos por gente importante, ligada à corte e talvez por pessoas, de uma maneira geral, que podiam pagar pelos sermões. Dito isso, o sobrinho lamenta o insucesso da primeira parte deles:

\footnotetext{
E posto q̃ a I. parte naõ foy tã festejada de muitos, como por vẽntura eraõ os papeis q̃ andauaõ de maõ, \& naõ faltaraõ algũs, aque pareceo o estilo das pregaçoẽs do Senhor Diogo de Payua, meo tio, ser já pouco costumado, \& que agora se prega cõ mais sutileza \& engenho (1604. fol. 2r).
}

O excerto informa sobre um dos modos de divulgação de textos no século XVII, que podiam circular, talvez em forma de livretos, ou folhetos, de "mãos em mãos". Outro dado interessante é que os sermões de Diogo de Payva foram publicados anos após serem proferidos e carregavam uma espécie de "marca de seu tempo", apreendida por meio da simplicidade do estilo, diferente dos sermões correntes no período em que escreve o sobrinho do autor, marcados pela "sutileza e engenho". Apreende-se que os sermões de Diogo de Payva soam como comuns ou "superados" em relação à linguagem, ou, nas palavras do autor do prólogo, formados por um estilo "pouco costumado". Infere-se também que eles possuíam um caráter mais simples se comparados 
àqueles que circulavam no início do século XVII e que, por isso, não agradavam a um público mais exigente. Diante dessa constatação, o sobrinho procura motivo para publicar o sermonário do tio, justificando-o nos seguintes termos:

Thiago

Maerki

[...] seruiraõ pera o outro pouo Christaõ, que terá aquy na sua propria lingoa Portuguesa pregaçoẽs das festas da Virgẽ N. Senhora, \& Sãtos, que poderaõ muy seguramẽte ler ẽ suas casas, \& a suas familias quãdo ou naõ ouuirẽ ou não entenderẽ pregaçoẽs mais doutas \& levantadas (1604, fol. 2v).

Os cristãos são divididos pelo autor em duas categorias: os doutos e os simples. A estes se destina a publicação dos sermões do tio, principalmente porque estão redigidos em língua portuguesa e podem mais facilmente ser compreendidos. Além disso, podem ser lidos em casa, em família, - o que revela uma prática de leitura muito interessante quando não conseguirem compreender as pregações ouvidas na igreja em decorrência de serem mais "doutas e levantadas".

O autor do prólogo, então, aproveita para criticar os pregadores mais preocupados com a "beleza do discurso" do que com o bem das almas:

Queira o Senhor que todos os que temos este officio de pregar, pretẽdamos com mor cuydado o bem das almas, \& encaminhar os ignorantes no caminho da saluaçaõ, que satisfazer a curiosidade dos que se tem por sabios, \& querem novidades mais pera entreter o entendimento, que pera melhorar a vontade $(1604$, fol. $2 v)$.

O excerto revela também uma prática de leitura consoante àquela que temos analisado em torno das legendas e crônicas hagiográficas escritas na Idade Moderna, isto é, que esses textos não eram lidos apenas para a instrução moral e religiosa, mas também para, como indica o próprio texto - embora sendo prática de leitura repreendida pelo autor - "entreter o entendimento".

Apesar de discutirem de maneira muito próxima a prática de leitura que deve ser levada a cabo pelo cristão, Frei Marcos de Lisboa, Bartolomé de Figueroa e o sobrinho de Diogo de Paiva parecem não concordar plenamente quanto a seus propósitos. Enquanto o frade menor e o poeta canário aceitam o deleite ocasionado pela leitura, o sobrinho do 
pregador, reconhecendo a existência de tal prática, parece não aceitá-la nesses moldes. Essa problemática surge com mais força no período da contrarreforma e se estende até o século XVIII. A leitura para o deleite é constantemente retomada e enfatizada nos textos de espiritualidade da Idade Moderna, ora para ser defendida, ora para ser condenada, contenda subjacentemente já no século XV. No De imitatione Christi (1418-1417), atribuído a Tomás de Kempis (1380-1471) - obra mais lida e editada da tradição cristã do Ocidente depois das Sagradas Escrituras -, por exemplo, recomenda-se: "Renuncia às meras curiosidades e escolhe leituras tais que possam te inspirar bons pensamentos mais do que Ensinar, movere distração" (KEMPIS, 2016, p. 46-47). Dessa maneira, o leitor não deve deleitar satisfazer suas curiosidades de leitura, que carece ser praticada com o propósito de autocontrole, ou seja, para ter bons pensamentos. No entanto, o cônego regular de Santo Agostinho não recrimina a leitura com a finalidade de "distração", apenas coloca em relevo que esse não deve ser o principal objetivo do cristão.

Muito provavelmente produzido no mesmo período do texto de Kempis, o anônimo Horto do Esposo, de finais do século XIV ou de inícios do XV, apresenta também interessantes apontamentos sobre essas "práticas de leitura". No prólogo, seu autor indica as intenções da obra: "Eu, mui pecador e nom digno de todo bem, escrevi este livro pera proveito e espiritual deleitaçom de tôdolos simpleses, fiees de Jesu Cristo, e espicialmente pera prazer e consolaçom da alma de ti, minha irmã e companheira da casa divinal e humanal (apud SPINA, 1991, p. 71). O "deleite espiritual" e o prazer constituem-se, pois, objetivos de tal obra. Sendo dedicada principalmente a uma interlocutora identificada pelo autor como "irmã", destina-se também a todas as pessoas simples, que não conheciam o latim, mas podiam ler português ou, ao menos, ouvir e entender as histórias narradas neste horto. Mais à frente, no mesmo prólogo, evidencia-se novamente o deleite, colocando-o entre as finalidades da obra: "em êste livro som conteúdo muitas cousas pera mantimento e deleitaçom e mezinha e consolaçom das almas dos homens de qualquer condiçom" (apud SPINA, 1991, p. 72).

$\mathrm{O}$ autor destina sua obra a homens de qualquer condição, o que revela, à semelhança do que já enfatizamos, um público muito alargado, de que ele nos dá exemplos: o rude, o sábio, o fraco, o tíbio, o enfermo, o cansado e o faminto (apud SPINA, 1991, p. 72). Isso muito se aproxima das intenções de Frei Marcos de Lisboa, que, no excerto há pouco trans- 
crito, parece fazer o mesmo ao destinar a Vida de santos a qualquer tipo de público: pessoas inclinadas à cavalaria; aqueles que se deleitam com a honra; os amantes da ciência; os ativos e contemplativos; enfim, qualquer pessoa que se julgue cristã. Não limitar o público alvo de seus textos pode ser estratégia alimentada pelo mercado livreiro impresso em ampla expansão. Nesse sentido, para indicar um exemplo relacionado a Portugal, basta transcrever um trecho do "Prologo ao avctor", escrito por Simão Lopez - que também era impressor e mercador de livros - presente na tradução portuguesa de um Flos Sanctorum castelhaThiago no, cujo autor é Alonso de Villegas (1534-1615), intitulado Flos sanctorum e historia geral da vida e feitos de Iesu Christo (1598): mais liuros: porque he hum liuro, que todo o genero de pessoa neste Reyno q̃ começa a tomar estado de casado, por costume mui louuado tem, que junto cõ as alfaias q̃ compra pera ornar sua casa, hũa dellas he este liuro. E em todas as casas do homẽ que tem primor \& honra neste Reyno se acha: porque nelle lé, \& passa as horas ociosas, \& dé recreação a molher, quãdo enfadada o domingo, ou dia sancto fica em sua casa: Nelle aprende a filha, a não se chegar a jenela na ausencia de sua mãy: Nelle os filhos passão as horas oportunas das noites largas do inuerno, pera euitar o jogo: Nelle os criados aprendem bõs costumes: \& as criadas \& escrauos, vendo tão boas cousas, ás vezes dão a sua ração ao moço que sabe lèr, pera que depois que os señores estão recolhidos, lhe lèam hũa vida de Sãcto do seu nome. E como este liuro ande por mãos de molheres, filhos, filhas, criados, \& escravos, he necessario \& importãte q̃ seja em nossa lingoajem Portuguesa, pera que esta gente de meão entendimento com mais amor se afeiçoe á sua lição. E esta he a razão porque este liuro somente tem este priuilegio, de elle sò ser necessario traduzirse em Portugues, o q̃ os outros liuros não tẽ, pois andão por mãos de quem entende o lingoajẽ castelhano (página inumerada).

Simão Lopez indica que os Flos Sanctorum possuem lugar de destaque dentre os demais livros impressos em sua época. Eles eram destinados a todos e aos mais variados tipos de público, inclusive aquele formado por quem não conhecia latim e, muitas vezes, também por pessoas que nem 
sequer podiam ler, mesmo em língua corrente, como os criados e os escravos. Também a esses são destinadas as Vidas de santo. Além disso, tal excerto evidencia a importância desse tipo de livro, que faz parte dos objetos indispensáveis, por exemplo, à casa de um homem e de uma mulher recém-casados. As narrativas santorais eram lidas ou ouvidas por todos os habitantes da nova casa: do pai de família, passando por sua esposa e filhos, até chegar, como acabamos de ler, àqueles que os serviam. Para alguns, tal leitura tinha como principal propósito o aspecto moral: ensinar à filha que não devia se aproximar da janela na ausência da mãe; e evitar que os jovens, nas noites de inverno, se entretivessem com jogos. Para outros, a Ensinar, movere leitura dessas narrativas era realizada também com o propósito do deleideleitar te. Desse modo, tais narrativas podiam servir de recreação à mulher quando enfadada aos domingos e dias santos, além de serem indicadas - como "passatempo", poderíamos afirmar - aos homens nos momentos de ociosidade. Até mesmo para os escravos e criados tais histórias serviam como diversão, quando, no silêncio da noite, depois de um longo dia de trabalho e enquanto os senhores estavam recolhidos, podiam ouvi-las do moço que sabia ler. E isso tinha seu preço! Essa prática de leitura em grupo, portanto, não se restringia ao momento das refeições monástico-conventuais, como seria natural supor. Extrapolava mesmo o âmbito litúrgico e se enraizava nas práticas de leitura das pessoas mais simples. Como lembra José Adriano de Freitas Carvalho, Jorge Cardoso escreve em seu Agiológio Lusitano que um ferreiro da vila de Penafiel, Afonso Fernandez Barbuz (?-1579), nas tardes dos domingos e dias de festa, em uma praça, costumava ler em voz alta e inteligível, a seus amigos e vizinhos, os Flos Sanctorum,

\footnotetext{
“tal como faria, muito mais tarde (1656), Dona Violante Henriques que, não podendo encontrar, em Lisboa, um exemplar dos Flos Sanctorum de P. de Ribadeneyra, lia, em Salvaterra, pelas noites de inverno, a seus criados e gente menos culta que vivia em sua casa, o De la afición y amor de María" (CARVALHO, 2007, p. 143-144).
}

A leitura comunitária realizada pelo ferreiro e pela futura clarissa revela também uma prática de caridade digna de ser imitada (CARVALHO, 2007). Apesar desses exemplos, teria sido, de fato, uma leitura possível das Vidas de santos? Ou teria sido, enquanto exercício piedoso, apenas incorporado nas hagiografias e biografias devotas como tópica poética de construção de personagem? Apesar de a resposta afirmativa 
não poder ser descartada, não é possível negar que tal modo de leitura fosse efetivamente colocado em prática. Para Carvalho, quando, em 28 de novembro de 1613, o conde de Gondomar, embaixador na Inglaterra, comenta que nas noites de inverno, em sua casa, juntavam-se à chaminé para lerem a vida de santo daquele dia, "não duvidamos, ante tão ilustre e chamativo exemplo, que era esse um costume muito mais corrente que poderíamos pensar" (CARVALHO, 2007, p. 144-145). De acordo com Moreno, por sua vez, os analfabetos possuíam duas maneiras de se beneficiarem das Vidas de santos: por meio das pinturas que apresentavam suas histórias ou "podiam se beneficiar da leitura em comum, tão característica dos tempos passados" (2008, p. 215).

Os Flos Sanctorum, como sugere o excerto há pouco transcrito de Villegas, tinham, ressaltemos, um duplo objetivo: ensinar e deleitar! Tal constatação não é difícil de supor, principalmente porque os santos eram tratados como verdadeiros heróis da fé, sendo as narrativas de seus feitos, muitas vezes, comparadas às de grandes personagens da literatura clássica. O santo é o herói cristão! A leitura de suas Vidas proporcionava prazer e apresentava modelos de santidade para serem seguidos pelos leitores. Foi com esses propósitos - durante a viagem que o levaria ao Brasil em 1570, não fosse o seu martírio e o de seus trinta e nove companheiros nas mãos dos calvinistas - que o padre jesuíta Ignacio de Azevedo jogou ao mar os livros levados pelos viajantes, oferecendo, depois, a alguns o De contempto mundi e a outros uma Doctrina e, para todos, em comum, um Flos Sanctorum de Braga - ou seja, a História das vidas e feitos heroicos e obra insignes dos sanctos (1567), de Frei Diogo do Rosário - orientando também um lugar onde ficasse de forma pública a todos os tripulantes. Teria, então, ordenado "que o Irmão Magalhaes lhes lesse todos os dias huma lição a huma hora certa por aquelle livro, na qual hora se ajuntavão muitos e folgavão muito de o ouvir (apud CARVALHO, 2007, p. 145). Assim, além do efeito moral ("ler uma lição"), a leitura desses Flos Sanctorum tinha o propósito de entreter os da nau, que se divertiam e descansavam ao ouvi-la.

No que tange à leitura de Vidas de santos e de Flos Sanctorum não parece indecoroso afirmar que fora realizada também com vistas ao prazer, como por várias vezes já assinalamos. No entanto, quando se têm em vista as crônicas historiográficas, tipo de texto que arrola para si o estatuto de verdade, tal prática de leitura parece não ser tão verossímil à primeira vista. $\mathrm{O}$ trecho transcrito das Crônicas é apenas um exemplo 
comprovativo dessa possibilidade de leitura. Tal aspecto fica também muito claro na aprovação "Do ordinário", escrita por Frei José de Jesus Maria (1690-1752), para o Claustro franciscano, erecto no domínio da coroa portuguesa... (1740), de Frei Apolinário da Conceição (1692-1755), irmão leigo, nascido em Lisboa, mas pertencente à província franciscana da Imaculada Conceição do Brasil. Após afirmar que seu autor soube recompilar em pouco papel o que escreveram dilatadamente diversos cronistas franciscanos, sendo ela útil para escritores futuros, considera também a obra "deleitavel para os curiosos da Historia: estimulo de devoçaõ para os inclinados ao Instituto Serafico: Vigurozo Fiscal, para arguir vicio dos Professores de Letras" (1740, páginas inumeradas). Como sugere esse trecho, os leitores que se interessam por crônicas historiográficas podiam se "deleitar" com a leitura deste "claustro franciscano".

Ensinar, movere deleitar

Outro exemplo interessante pode ser colhido do "Prologo ao Leitor", presente no Espelho de Penitentes e Chronica de Santa Maria da Arabida... (1737), do já citado Frei José de Jesus Maria:

\footnotetext{
Censuraõ os nimios escrupulosos das regras da Historia qualquer reflexaõ, que a Historia se faça, sem advertir para a dissimular, que poderá servir para documento Politico, Mystico, ou Moral do Leitor, que busca na liçaõ dos livros naõ só a recreação dos sentidos, mas o aproveitamento do espirito (1737, página inumerada).
}

De acordo com esse excerto, leitores procuram na leitura de crônicas historiográficas tanto o "aproveitamento do espírito" (ensinamento moral) quanto a "recreação do espírito" (entretenimento). Mais adiante, tratando de críticos "escrupulosos", que fazem da própria obra examinada pedra para afiarem suas espadas, das quais nenhum escritor pode escapar, acusa-os de persuadirem-se de "que o Author enriquecendo de varias noticias a sua Historia, intenta saborear o appetite dos que a desejaõ saber, para que se naõ enfastiem da leitura dilatada de uma sò materia" (JESUS MARIA, 1737, página inumerada). Os cronistas parecem ser acusados de alimentarem suas narrativas com dados desnecessários, impróprios ao gênero cronístico, com o objetivo de satisfazerem o apetite de seus leitores que, caso contrário, poderiam se cansar da leitura monótona e, por inúmeras vezes, digressiva. Os cronistas, muitas vezes, são acusados por esses críticos de se desviarem da matéria tratada, ao que Frei José de Jesus Maria redargui: “Anathematizaõ as digressões, sem examinar 
com atençaõ, se por algum principio poderaõ pertencer ao assumpto da matéria, sobre o que se escreve" (1737, página inumerada).

Tratando também do problema dos críticos no prólogo "Ao leitor" de sua Chronica da Provincia da Piedade (1696), Frei Manoel de Monforte (?-1711), pregador e filho dessa província franciscana, declara que "estão os leitores tão enfastiados de varia lição dos muitos livros, que jà pela maior parte os não lem, senão por curiosidade, e divertimento; e assim se algum defeito nelles imaginão, o publicão nas ruas, e praças" (1751, página inumerada). $\mathrm{O}$ autor critica aqueles cujo objetivo de leitura é soThiago mente satisfazer suas curiosidades ou encontrar diversão, o que, parece Maerki estar implícito, não é o objetivo principal de sua obra. No mesmo prólogo, Monforte revela o verdadeiro objetivo da obra: trazer à memória a santi238 dade, a virtude e a vida dos antigos religiosos de sua província, "para que assim [os leitores] aspirem à mesma; que esta força tem o exemplo” (1751, página inumerada). Essas palavras sugerem novamente um conflito entre práticas de leituras, uma mais voltada para distração (dos críticos curiosos) e outra para o ensinamento moral (dos religiosos da Província Franciscana da Piedade, nesse caso específico, e os cristãos de um modo geral).

Deixando de lado esse embate entre cronistas e críticos, percebe-se que as crônicas historiográficas podiam suscitar também o deleite, ao menos de parte de seus leitores. É o que sugere também Frei Manuel da Assunção na licença "Da Provincia", constante na Primazia serafica na regiam da America (1733), do já citado Frei Apolinário da Conceição, ao dizer que tal obra "se faz grata ao entendimento, e deleitavel ao gosto" (página inumerável).

Apresentamos, agora, um último exemplo desta "leitura como deleite", ou "leitura para folgar", ou ainda "leitura para entreter o espírito", como a têm denominado os autores destacados. Colhemo-lo da "Aprovação" presente no Paraiso mystico da Sagrada Ordem dos Frades Menores (1750), de Frei Antonio Caetano de S. Boaventura (1669-1749), escrita por Frei Manoel do Espírito Santo. Sobre o autor e sua obra, ele afirma

[...] que deste scientifico Author já tem admirado o Orbe literário, muito mais se augmentarà agora o affecto nos devotos da Sagrada Ordem dos Menores, e o espiritual divertimento nam deixarà de ser sempre buscado com grande ancia entre tantas, estaõ fragantes descobertas neste theatro da mais deliciosa agricultura. Tudo em hum Paraiso saõ delicias para a vista, recreo para o gosto, e lisonja para o olfato, e entrando todos os 
sentidos do corpo humano a procurar alivio em tam agradavel hospicio de Flora, nenhũ se desapega do liberal regalo, q̃ ali se lhe apresenta" (página inumerada).

"Espiritual divertimento", "recreio para o gosto" e "liberal regalo"; expressões reveladoras da prática de leitura que temos examinado. À semelhança do "Paraíso Celeste", em que tudo são delícias, nesse "Paraíso Seráfico" o leitor poderá encontrar o alívio e descanso procurados. Isso é o que apresenta também Padre José da Costa, qualificador do Santo Ofício, nas "Licenças do Santo Ofício", presente na mesma obra, ao dizer que entrou "com summa recreaçaõ, e gosto nas delicias deste Paraiso Mystico" e que "tudo gozarà o leytor, se se recrear no Paraiso deste livro" (página inumerada). De igual modo, na "Aprovação do Ordinário", Frei Feliz do Rosário

Ensinar, movere deleitar qualifica esse Paraiso Mystico como "deliciosa obra” (página inumerada).

Todos esses paratextos são unânimes em avultar que a leitura da obra de Frei Antonio Caetano não se destinava apenas à instrução moral, como modelo de conduta, ou como instrumento catequético. Objetivava, além disso, o deleite de seus leitores, os quais procuravam na leitura um momento de distração, de recreação e de diversão.

\section{Considerações finais}

No arco temporal que vai do século XVI ao XVIII, dentre essa massa cada vez mais crescente de textos religiosos, destacam-se, como já afirmamos, os textos hagiográficos; os santos eram venerados e cultivados pela maravilha que representavam, pelos milagres que realizavam, pela vida diariamente provada, pelas batalhas travadas contra os demônios, pela superação de que somente um verdadeiro herói da fé poderia dar provas. Na leitura desses textos santorais, presentes nos inúmeros hagiológios, Flos Sanctorum, Vidas, crônicas historiográficas, sermões, poesias e outros tantos, o "devoto leitor" encontrava, assim, muito mais que apenas modelos de santidade. A leitura pelo deleite, embora muitas vezes condenada, era prática comum. E tinha também o objetivo de mover seus leitores à ação, à prática cristã. Ensinar, mover e deleitar compunham, pois, inseparavelmente, a prática de leitura (e escuta) dessa imensa gama de textos religiosos; prática essa que deve ser considerada pelos estudiosos do período ao examinarem seus textos-objeto, tendo em vista que a desconsideração desse aspecto, evidentemente, poderá levar à precipitadas e improváveis conclusões. 


\section{REFERÊNCIAS}

ALVAREZ, Antonio. Primera parte de la sylva spiritval de varias consideraciones, para entretenimiento del alma Christiana. Lisboa: Em casa de Simon Lopes, 1594.

ASSUNÇÃO, Manuel da. Da província. In: CONCEIÇÃO, Apolinário da. Primazia serafica na regiam da America, novo descobrimento de santos, e veneraveis religiosos da Ordem Serafica. Lisboa Occidental: Na Officina de Antonio de Sousa da Sylva, 1733.

Maerki

BERNARDES, Manoel. Nova floresta, ou sylva de varios apophthegmas, e ditos sentenciosos espirituaes, \& moraes. Primeyro Tomo. Lisboa: Na Officina de Valentim da Costa Deslandes, 1706.

Nova floresta, ou sylva de varios apophthegmas, e ditos sentenciosos, e moraes. Quarto Tomo. Lisboa Ocidental: Na Officina de Joseph Antonio da Sylva, 1726.

CARVALHO, José Adriano de Freitas. Lectura espiritual en la Península Ibérica (Siglos XVI-XVII). Programas, recomendaciones, lectores, tempos y lugares. Salamanca; Porto: Seminario de Estudios Medievales y Renacentistas; Centro Interuniversitário de História da Espiritualidade, 2007.

Coleçaõ, e escolha de bons ditos, e pensamentos moraes, políticos, e religiosos. Lisboa: Na Offic. de Francisco Borges de Souza, 1779.

CONCEIÇÃO, Apolinário da. Claustro Franciscano, erecto no dominio da Coroa Portugueza. Lisboa Occidental: na Off. de Antonio Isidoro da Fonseca, 1740.

COSTA, José da. Licenças do Santo Ofício. In: S. BOAVENTURA, Antonio Caetano de. Paraiso mystico da Sagrada Ordem dos Frades Menores. Porto: Na officina de Manoel Pedroso Coimbra, 1750.

D’ANDRADE, Diogo de Paiva. Sermões do Dovtor Diogo de Payva D’Andrade. Segunda Parte. Em Lisboa: Impresso por Pedro Crasbeeck, 1604. 
ESPÍRITO SANTO, Manuel do. Aprovação. In: S. BOAVENTURA, Antonio Caetano de. Paraiso mystico da Sagrada Ordem dos Frades Menores. Porto: Na officina de Manoel Pedroso Coimbra, 1750.

FIGUEROA, Bartolomé Vairasco. Templo Militante Flos Sanctorum, y Trivmphos de svs virtvdes. Primera y Segvnda Parte. Lisboa: por Pedro Crasbeeck, 1613.

Ensinar,

Horto do esposo. In: SPINA, Segismundo. Presença da Literatura movere Portuguesa. Era Medieval. Rio de Janeiro: Bertrand Brasil, 1991.

deleitar

JESUS MARIA, José de. Espelho de Penitentes e Chronica de Santa Maria da Arrabida. Lisboa Occidental: Na officina de Joseph Antonio da Sylva, 1737.

. Do ordinário. In: CONCEIÇÃO, Apolinário da. Claustro Franciscano, erecto no dominio da Coroa Portugueza, e estabelecido sobre dezeseis Venerabilissimas Columnas. Lisboa Occidental: na Off. de Antonio Isidoro da Fonseca, 1740.

KEMPIS, Tomás de. Imitação de Cristo. Tradução de Leonardo Boff. Petrópolis: Vozes, 2016.

LISBOA, Marcos de. Crónicas da Ordem dos Frades Menores (Edição fac-símile em 3 tomos). Porto: Faculdade de Letras da Universidade do Porto, (1614) 2001.

MADRID, Alonso de. Espejo de ilustres personas. In: Misticos Franciscanos Españoles (Tomo I). Madrid: BAC, 1948.

MONFORTE, Manoel de (Frei). Chronica da Provincia da Piedade. Lisboa: Na officina de Miguel Manescal da Costa, 1751.

MORAES, Pedro Joze Suppico de. Collecçam Moral de Apophthegmas memoraveis. Parte I. Lisboa Oriental: Na officina Augustiniana, 1732. 
Collecçaõ moral de apotegmas, ou ditos agudos, e sentenciosos. Parte II. Coimbra: Na Officina de Francisco de Oliveyra, 1761.

MORENO, Álgel Gómez. Claves hagiográficas de la literatura española (del Cantar de mio Cid a Cervantes). Madrid: Iberoamericana, 2008.

ROSÁRIO, Feliz do. Aprovação do Ordinário. In: S. BOAVENTURA, Antonio Caetano de. Paraiso mystico da Sagrada Ordem dos Frades Menores. Porto: Na officina de Manoel Pedroso Coimbra, 1750.

Maerki

STOCK, Brian. Ethics through literature. Ascetic and aesthetic

242 reading in Western Culture. Hanover; London: University Press of New England, 2007.

VILLEGAS, Alonso de. Flos sanctorum e historia geral da vida e feitos de Iesu Christo, Deos Nosso Senhor e de todos os Sanctos. Em Lisboa: em casa de Simão Lopez, 1598. 